\title{
Is it possible to be accommodative of other religions as a school principal?
}

\author{
Maitumeleng Albertina Nthontho ${ }^{1}$
}

Published online: 3 January 2018

(C) The Author(s) 2018. This article is an open access publication

\begin{abstract}
In 2003, when the Department of Education in South Africa promulgated its National Policy on Religion and Education, Religion Education was introduced in schools. One of the aims of this policy was for public schools to promote, protect, respect and instil the core values of a democratic society through their processes and practices. The role of the school principal has been to mediate implementation of this policy. Since then, religion in schools has been a complex and contested subject. While acknowledging these contestations, this article focuses on whether or not it is possible for school principals to be accommodative of other religions. More specifically, the argument informing the article is that it is not only possible, but also necessary, in terms of the principals' mandate to mediate policy implementation in schools. In so doing, the article reports on the narratives of the twelve purposefully selected school principals on how they implement the religionin-education policy in their respective schools. The findings show that previous experience and insufficient training play an important role in influencing school principals' decisions towards policy implementation. Recommendations are therefore made.
\end{abstract}

Keywords Religious accommodation - Religious discrimination - Religious beliefs and practices $\cdot$ Religious education $\cdot$ Religious diversity

\section{Introduction}

In the era of Human Rights, every citizen of the world has the right to value and celebrate his/her own faith without fear of persecution or discrimination. However, the question of religious accommodation has been debated at length in South African schools and elsewhere. An increasing number of costly and protracted court and legislative battles between

Maitumeleng Albertina Nthontho

mnthontho2014@gmail.com

1 Department of Education Management and Policy Studies, Faculty of Education, Cnr Leyds and George Storrer, Groenkloof Campus, University of Pretoria, Pretoria 0002, South Africa 
schools and parents are evident to this reality. These debates have led to schools faced with lawsuits for violating the religious rights of both learners and staff by refusing to accommodate their religious beliefs and practices in organised school religious observances.

For instance, in 2014, an Organisation for Religious Education and Democracy (OGOD) in South Africa filed an application in the Gauteng High Court seeking to prohibit six public schools from advertising themselves as exclusively "Christian" or as having a "Christian ethos" (Thamm 2014). The High Court in Johannesburg condemned such practices by schools in 2017 stating that no public school may promote a single religion to the exclusion of other. In so doing, the High Court in a way encourages religious accommodation within schools (Greyling 2017).

We learn about a similar ruling on two court cases in Canada. On one case, (Cylberberg v. Director of Education of Sudbury Board of Education, 1988), the Ministerial regulation instructed public schools to open with a citation of the Lord's Prayer or "other suitable prayers" every morning. On the other, (Corporation of the Canadian Civil Liberties Association v. Ontario, 1990) the school board claimed its right to permit religious instructions in its schools. In both cases, the Ontario Court of Appeal ruled that in the Ontario public schools, it is permissible to "teach about religion", but not to "teach religion", or attempt to inculcate any type of religious belief (Peters 1998). In contrary to the above cases, LaFollette (1989) reports that the appellate court overturned the decision over a similar court case of which the U.S. Supreme Court refused to hear an appeal. As a result the parent's case is dead.

While some of these tensions are taken to courts of law, others occur outside of courts' grounds. For examples $\mathrm{Li}$ and Moore (2014) cites the existing tensions between the traditional faith-based education provided by Theravāda Buddhist temple schools and secular state education in China. In Nigeria, there is an ongoing religious crisis between Muslims and Christians (Sulaiman 2016; Fatima 2014; Ekanem and Ekefre 2013). The evidence of this is the incident of 2014 where Boko Haram from Chibok kidnapped 276 school girls. These girls are reported to be among thousands of people abducted by Boko Haram over the years (Ekanem and Ekefre 2013). Research reveals that textbooks used in Pakistani primary and secondary schools foster prejudice and discrimination of religious minorities, especially Hindus and Christians (Hussain et al. 2011). These occurrences set a reasonable evidence that contradictions and contestations with regard to religion in education have become a worldwide phenomenon. As they occur, they do not only cause harm to perpetrators, instead they become a seed sawn into the lives of the growing generations (Ekanem and Ekefre 2013).

In this article, I first provide a brief overview of religious discrimination from both local and international perspectives. This will enable me to create a picture of how individual countries dealt and still deal with religion in schools. I hope this background will give an understanding of the religious journey walked by the school principals in this study whose experiences are behind this article. I then look at the concept of religious accommodation as one of the virtues I argue to be necessary when implementing contentious policies such as that of religion-in-education. To this purpose, special cases relating to the issue under scrutiny are cited, mainly as a means of strengthening my argument. 


\section{Religious discrimination in education and implications}

Soon after it gained the political power in 1948, the National Party (NP) designed and introduced new education policies such as the Bantu Education Act of 1953. In 1967, the NP government deliberately advanced the ideology of 'Christian national education' making it the official education policy. The Christian national education taught in public schools did not only give preference to a particular Christian Protestant religious doctrine based on Calvinism but also to an ideology spawned from apartheid principles. Religious Instruction classes served as opportunities for evangelism and the nurturing of Calvinist values and principles. Parent communities not in favour of this were denied equal opportunities to develop their own religious orientations and cultures (Mitchell 1993).

Most of the State schools in South Africa taught Bible education and learners attended such classes irrespective of whether they were Christians or not. Learners were coerced to accept Christian national education with its underpinning philosophies and assumptions. For example, Sundays were observed as days of rest, and certain forms of entertainment were taboo on Sundays (Sooka 1993). Independent schools based on other religious orientations, while allowed, had to adhere to the apartheid policy of racial separation. That is, although provision was made for learners with a Muslim or Hindu religious orientation in public schools controlled by the House of Delegates, ${ }^{1}$ learners from religions other than Christianity were denied equal freedom and treatment. Additionally, Christian doctrines denounced some of the traditional beliefs and practices and by so doing, destroyed even the good that prevailed in South Africa (Frankema 2012; Marashe et al. 2009).

South Africa is no exception from the way religion was dealt with in public spaces. Upon its arrival to power in 1949, the Communist Party of China (CPC) demonstrated commitment to shaping Chinese society according to a specific worldview based on science, and for which the tenets of atheism were a necessary foundation (Laliberte' 2016). That is to say, the CPC government pronounced its neutrality by treating religion as culture and freedom not to believe in religion is stressed (Marshall 2016). As a result, religions became the target of oppression to an extent of their dismissal and denouncement with the hope that the followers would abandon them (Nanbu 2008). The government initiated a series of campaigns and mosques were closed or destroyed, religion was made a crime and followers were arrested and imprisoned (Marshall 2009). Because of these restrictions on religious freedom, one would argue that there is no religious freedom in China, there is rather religious persecution (Guo and Zhang 2015).

It is however worthy to note that the CPC government legalised only five religions to operate in China. These include Buddhism, Daoism, Islam, Catholicism, and Protestant Christianity provided they register their membership with "patriotic" associations (Marshall 2016). We further learn that religion has never had a substantive role in the formal curriculum of Chinese government schools, where the majority of students are educated even today (Jackson 2015). Regardless of the legal status of the five religions, China does not allow schools to provide religious education for minors (Hornemann 2013).

In contrast, Canada views schools as vehicles to preserve and extend Christian civilisation in the new world (Peters 1998). Many schools in Quebec are reported to be the responsibility of the churches since 1960s and because the majority of the population was Catholic, the Roman Catholic Church took charge (Peters 1998). Christian practices such

\footnotetext{
1 An education department created specifically to serve the Indian community in South Africa.
} 
as prayers, Bible readings, religious instruction classes, Christmas and Easter celebrations complete with God, Christ and angels are therefore a norm regardless of a child's religious faith (Lupul 1969). Similarly, religious education classes are compulsory in Australia and they are held for all students (Gellel and Buchanan 2011). In Malta, religious education with the Catholic tradition is a compulsory subject (Gellel and Buchanan 2011). It is worth mentioning however that the Quebec Charter of Human Rights and Freedoms (1975) and Malta, House of Representatives (2009) gave parents the right to exempt their children from religious practices that are against their religious beliefs. Nonetheless, evidence suggests that withdrawal of children from religious practices has not been an effective solution (Gellel and Buchanan 2011; Mawhinney 2007; Lupul 1969).

Grounded from the above religious practices, I discover two approaches to religious discrimination namely "fair" and "unfair". By fair religious discrimination, I would like to cite the case of China where almost all religions are non-existent in the school curriculum. Where permissible, the principle of "reasonably applicable" is considered. That is, if religious education is allowed in schools, minors are excluded (Hornemann 2013). Religious practices that unfairly discriminate against other religious beliefs are observed in countries such as Canada, Nigeria, Australia, South Africa, to cite but a few of them. Although religious practices are permissible in schools, provision is made for certain religions, Islam, for instance, not all (Peters 1998; Gellel and Buchanan 2011). This article therefore defines "unfair" religious discrimination to be those processes and practices that provide unequal treatment to religions in a particular community.

A lack of respect for the full diversity of people and their beliefs and practices (Bilchitz 2011) results in most religious groups knowing very little about the customs, beliefs, and rituals of each other. It is therefore not surprising that groups with different religious orientations were, and still tend to be, suspicious and intolerant of those with different religious orientations (Ekanem and Ekefre 2013). Put differently, respect often comes from understanding and knowledge whereas fear comes from ignorance (Chidester 2002). Fair treatment of religion in schools would therefore play an important role in promotion of religious accommodation within societies. I therefore see the school principal at the heart of the implementation of the legislation and policies that demand a complete change of the cultures of the schools and of their roles.

Realising the sensitivity of the phenomenon under study and the religious experience of the school principals, I argue that executing such responsibility may not be easy for them. I base my argument on the fact that their education and religious accommodation among others can serve as tools to effective implementation of religion policies in schools (Scott and McNeish 2012; Chidester 2002). Before discussing how school principals in this study executed their responsibility, I find it imperative to present what, according to research, religious accommodation is as well as its implications.

\section{Religious accommodation and implications}

From the discussions in the previous sections, there is a clear indication that almost all the world countries are singing one song-religious freedom by citizens of the world. Both Articles 9 and 18 of the European Convention on Human Rights and United Nations Universal Declaration of Human Rights respectively, provide for the right to freedom of thought, conscience and religion (EU 2010; UN 2015). These Articles enable, empower and support citizens, young and old, of every member state to practise his/her religion 
freely without fear of persecution. By implication, every member of the states that are signatories to these Conventions and Declarations are therefore obliged to respect, protect, promote and instil these rights and freedoms in all their processes and practices. That is to say, there is a need for mind shift away from the "unfair religious discrimination" to "religious accommodation".

In line with Article 18 of the Universal Declaration of Human Rights (2015), Section 15 (1) of the South African Constitution guarantees individuals freedom of religion and belief, categorically stating that "everyone has the right to freedom of conscience, religion, thought, belief and opinion". Section 15 (2) points out that religious observances may be conducted at State or State-aided institutions, provided that (a) those observances follow the rules made by the appropriate public authorities; (b) they are conducted in an equitable manner; and (c) their attendance is free and voluntary (RSA 1996a). In alignment with the Constitution, the South African Schools Act (1996b) (SASA) contains a pledge of the State to protect and advance the diverse South African cultures and languages, and to uphold the rights of all learners, parents and educators (RSA 1996b). More specifically, this Act (84 of 1996b) stipulates that, subject to the Constitution and any provincial law, "religious observances may be conducted at a public school (a) under rules issued by the governing body, (b) if such observances are conducted on an equitable basis, and (c) attendance at them by learners and members of staff is free and voluntary" (Section 7 of the Schools Act, 1996b).

Although the African National Congress (ANC) government already realised the importance of developing a policy that specifically deals with religion in schools in 1994, it was not until 2003 that it released such a policy due to lengthy and highly charged debates. Its intention is to encourage schools to promote reconciliation-to bridge the religious divide through a greater understanding of others (DoE 2001), to ensure peace and tolerance amongst learners belonging to widely different religious affiliations (Abdool et al. 2007), to help learners understand the colourful religious heritage of the country, thus developing respect for other human beings while simultaneously closing the geographical and religious gap between various communities in the country - a space created in the name of civilisation and Christianity (Mkhatshwa 1998).

Put differently, the ultimate aim of the policy is to promote religious freedom, pluralism, diversity, tolerance, respect, justice, compassion and commitment in young South Africans (Abdool et al. 2007). In spite of its clearly educational aims (Chidester 2003), the religion policy in schools provoked a storm of controversy (Chisholm 2005). According to Roux (2001), attempts and initiatives to change the religion education programmes in schools were received with hostility by many individuals and groups in the religious, educational and public spheres. Since then, religion policy in South African schools has been contested in and outside courts of law. In some schools learners and educators subscribing to other religions are not allowed to observe their religions in terms of dress code, among others. In others, ceremonies and orientations where one religion is practised are compulsory (see Sect. 1 for more).

Viewing religious accommodation and its implications from an international perspective, we find a similar pattern in Pakistan. In his "preamble" (1876-1948), the founder of Pakistan, Mohammad Ali Jinnah, pronounces that:

Minorities, to whichever community they may belong, will be safeguarded. Their religion or faith or belief will be secure. There will be no interference of any kind with their freedom of worship. They will have their protection with regard to their 
religion, faith, their life, their culture. They will be, in all respects, the citizens of

Pakistan without any distinction of caste or creed (Hussain et al. 2011).

Despite the provisions above, the majority of the studies conducted contradict the preamble. For instance, the study by Nayyar and Salim (2003) concludes that the rights of religious minorities - while partially codified in the Constitution of 1973-are not protected by the State. The State promotes Islam as a dominating force and it is often made to encroach upon the lives of religious minorities. According to this study, the curricula of the public school system exhibit many points of concern. In particular, this study found the importance of Islamic teaching as well as the Islamic nature of Pakistan being emphasized, while hatred was espoused towards Hindus and Indians (Hussain et al. 2011).

According to Article 36 of the Constitution of the Republic of China (2004), "Every citizen shall enjoy freedom of religious belief." It goes on to say, "No state organ, public organisation or individual may compel citizens to believe in, or not to believe in, any religion; nor may they discriminate against citizens who believe in, or do not believe in, any religion." In this way, the Republic of China is in the mission to protect, promote, respect and instil normal religious activities within the state. However, some limitations go along with these provisions. In this regard, the Article states clearly, "No one may make use of religion to engage in activities that disrupt public order, impair the health of citizens or interfere with the educational system of the state. Religious bodies and religious affairs are not subject to any foreign domination." (Republic of China 2004).

However, regardless of their legalised status, these religions, Buddhism in particular, never enjoyed their freedom in China. Buddhist temple education (BTE) has been criticised for its backward education form that impedes educational reform and threatens to widen ongoing economic and educational disparities between the Han and the Dai (Li and Moore 2014). Educational policies in China seldom usually ignore the role of religious education as a tool for maintenance ( $\mathrm{Li}$ and Moore 2014). To make matters even worse, Hornemann (2013) mention that the state also discourages religious activity on general university campuses. These restrictions reflect the authoritarian State's desire to control religious groups, including by intervening in the training of their leaders and the level of education of their members (Xie et al. 2017). In other words, State regulations and practices determine how many and how big such institutions can be and what they can and cannot teach (Hornemann 2013).

In Canada, the Constitutional Act of 1982 provides for freedom of conscience and religion. However, Christianity remains a dominant religion (Peters 1998). In Wales, while staff members generally come from a wide variety of social, cultural and religious backgrounds, the posts of head teacher, deputy head teacher and head or coordinator of Religious Education are to be filled by none other than the baptised and practising Catholics (Welsh Government 2011).

In a nutshell, being seen as, for instance, a Christian in Western nations helped diminish hateful behaviour toward newcomers. Self-identifying as anything other than Christian would therefore put at risk a precarious community status and the chance of belonging to key social and political networks (Marshall 2016). Subsequently, if the Chinese government requires communist party members to profess a belief in atheism, I profess a belief in atheism and keep my Buddhist beliefs private (Shortle and Gaddie 2015). If the racist legislation in Canada prevents me from voting, I self-identify as Christian with the expectation that my life will get better (Marshall 2016). Kayaoglu (2015) found out that Muslim actors initiate interfaith dialogue in response to dissuade powerful international and domestic actors from perceiving the Muslim actors as radical and, thus, dangerous. 
Informed by religious processes and practices in the States as presented above, it is apparent that religious accommodation in education remains a contested and hotly debated issue. For this reason, States have opted to sub-contract into the International Conventions and Protocols' directives through compliance to legislative instructions only. Sub-contracting in this article refers to a strategy in which the State parties implement the intended religious change according to the wishes of a particular interest group or body (i.e., EU or UN). In other words, a number of the countries adopted some of the clauses relating to freedom of religion into their policies, not necessarily with the intention of applying them in their daily school lives, but to technically or administratively comply with the directives of International Conventions and Protocols.

For instance, even though studies conducted in countries cited in this article acknowledge declaration of religious freedom in these countries, there is enough evidence that religious accommodation is on the surface. Marshall (2016), Koesel (2015), Guo and Zhang (2015) discovered that the Chinese government opened doors for diverse religious practices only for it to integrate into globalisation. What this implies is that, China and its compatriots are not religious accommodative, instead, they are "politically accommodative to religious diversity" (Lamba 2016). Because of globalisation and economic ties, these countries sub-contract into International Conventions and Protocols relating to religion.

Grounded from the discussions above this article defines reasonable religious accommodation as an assurance of the effective and full enjoyment of freedom of religion. Drawing my conclusion to the school environment, reasonable religious accommodation as a process in which the governing body of the school (SGB) drafts the religion policy of the school in a manner that allows learners and staff from diverse religions to equally observe their religions. It is however my understanding that a reasonable religious accommodation would be required in school situations where the learner and/or staff member's religious beliefs, observances or practices may conflict with a specific task or job requirements. Nonetheless, factors such as multiple understandings of religion in education and religious illiteracy appear to be responsible for religious exclusions and unfair discriminations that exist in schools.

In this article, I argue that religious accommodation can possibly become the mainstream solution to resolving religious conflict. However, it is important to mention that one accommodates what he/she is knowledgeable about and understands better. It is a reality therefore, that there is substantial differences when it comes to the "name" to be given to the "study of religion in schools", its "aims and approach" (Grelle 2005). For instance, the approach to Religious education and religious studies continue to be instrumental rather than reflective (Gross 2010). The former refer to the inculcation of particular religious viewpoints while the latter involves critical interaction between the learner and knowledge (Rosenblith and Bailey 2008). Regardless of these differences, the fact of the matter is that the former prevails in most schools (Ekanem and Ekefre 2013).

When people are not well informed or lack knowledge about other people's customs, beliefs, and/or rituals, they suffer from religious illiteracy (Sulaiman 2016; Ekanem and Ekefre 2013). Kaidaulovna (2012) describes religious illiteracy as ignorance of the faith and cultural practices of others (Roebben 2010), why they believe what they claim, and how one can reconcile his/her own belief with other beliefs that seem incompatible with his/her own religious affiliations (Rosenblith and Bailey 2008). For example, the little understanding about Islam has resulted into Muslims often stereotyped as religious fanatics, terrorists, and a mysterious "Other" that represents a direct threat to Western civilization (Fatima 2014; Moore 2009). As Sulaiman (2016) puts it, the inability to 
recognise and accommodate views and opinions of others is therefore, one of the major sources of religious violence the world continues to experience.

Following these discussions, I present the methodology through which I gathered the experiences of school principals with the aim of determining the extent to which religious accommodation/discrimination enabled/disabled them to fulfil the mandate of the department of education as policy implementers at their schools. I will finally present and discuss their experiences in a form of findings that will be followed by conclusions and recommendations.

\section{Research methodology}

\subsection{Research design}

The study followed a qualitative research approach. This research approach enabled me to explore and understand how school principals mediate religion education in their schools, hence qualitative investigations focus on the experiences of participants as they are lived, felt and narrated (McMillan and Schumacher 2014; Johnson and Christensen 2012). Due to the limited work done on the phenomenon described in this study, the study employed the phenomenological research design, seldom used to study principals' experiences that influence their thoughts, actions and choices of strategies when implementing the policy (Grey 2014; Monette et al. 2014).

\subsection{Sampling}

Purposive sampling was employed and school principals, who were postgraduate students at the University of Pretoria, were purposefully selected as research participants (Patton 1990). One main reason for the choice of this sampling technique is that, since it is not the intention of the study to generalise findings, but rather to enhance understanding of principals' experiences of different religion policies as well as of their mediating role in implementing such policies in schools, purposive sampling was the answer. These principals participated in their private capacity, not as spokespersons of specific schools. That is, they narrated their stories as they experienced implementation of religion policy, not as per the expectations by their Departments of Education. When fieldwork took place, these school principals were (a) engaged in leadership and management training at postgraduate level; (b) had been in education for at least 15 years; (c) had been exposed to various religion-in-education policies, and (d) were from various religious orientations, language and cultural groupings.

\subsection{Participants}

School principals who were postgraduate students at the University of Pretoria, who met the above criterion and were willing to participate were invited to do so. Twelve principals became the sample of the study. The sample comprised of school principals from Gauteng, Limpopo, Mpumalanga and Kwa-Zulu Natal provinces. Although they appeared to be from one region (Northern region), their leadership backgrounds and experiences would be very different from one another's. Moreover, even though this was not the focus of the study, it would be of the audience interest to note that the study was gender and race balanced. Only 
three religions were represented. These were Hinduism, Islam and Christianity was dominant.

\subsection{Data collection}

Data were collected by means of narrative interviews, with school principals' stories being recorded, transcribed, analysed and interpreted. Religious issues are usually debated and discussed at a sentimental level or are elevated to litigation through the courts. Thus, the subject is rarely explored scientifically. Contrary to this, I made use of narrative inquiry to examine principals' experiences about religion that are not clouded by emotions/sentiments. In doing so, I was able to go beyond probing what principals like or dislike about the religion-in-education policy (Clandinin et al. 2010; Craig 2010). Data were collected from the University of Pretoria, South Africa in 2012/2013 over a period of 4-5 months.

\subsection{Ethics considerations}

Ethics approval that granted me permission to involve the principals/postgraduate students in the study was obtained from the Faculty of Education, University of Pretoria. Invitations were then directed at school principals - through direct and/or e-mail contact-who were willing to participate regardless of gender, province, historic origin and the type of schools (secondary or primary) in which they worked.

\subsection{Data analysis}

I transcribed principals' tape-recorded interviews and analysed transcriptions in terms of the initially identified categories (Babbie 2014). These included principals' understanding of their mediating role in religion policy implementation from which themes such as policy development, learner admissions and educator appointment, teaching about religion, as well as religious observances emerged.

\subsection{Trustworthiness of the results}

The raw data (tape-recorded interviews), interview transcripts, interview guides, list of participants and their profiles, as well as the field notes, were audited throughout the study period to validate their accuracy and authenticity (Craig 2010). In addition to this, I sent transcriptions to participants, asking them to correct errors of fact. This ensured that I represented them and their ideas accurately (Mertler 2006). Finally, the study went through the program called 'turn-it-in', as per the university's requirements, to ensure its originality.

\section{Study findings and discussions}

\subsection{Findings}

From the data presented in this study, it is evident that regardless of how explicit the laws and policies are in terms of religious rights and freedoms, school principals in this study regard a single-faith approach as the only way to deal with religion in their schools. They 
feel that by forcing schools to implement the policy, the government is interfering provocatively in the running of schools. One of the principals expressed the view that 'forcing a different style, a different way of doing things, causes conflict which tolls the other school activities and we are not happy with the enforcement that is going on in our schools'. The other principal reflected that 'one of the completely strange things to me is the request that we have to release 35 Muslim learners to leave for Mosque at 12:00 on Fridays'. This clearly indicates that most of the principals could not accommodate differences. It would therefore be difficult for them to lead the way in accommodating diverse religions in schools as required by legislation.

It was mentioned earlier on that one of the values religion education is intended to promote is tolerance. When it is applied in a spirit of tolerance, reasonable religious accommodation allows religious groups to live in harmony in the respect and acceptance of their diversity. This was, however, found not to be the case with the principals with a Christian orientation in this study. According to them, Christianity enables them to promote moral values and acceptable norms and principles to learners and staff. In the words of one of the principals, religious instructions were "morally good because it showed us the way, love for people, respect for other people, you know, this I believe is the correct way of doing things; this is the correct way of living. So, that is the reason that I say, what I learnt then, it is still part of me".

It appeared also from their narratives that most of the parents supported the way these principals deal with religion in schools. According to the other principal, "all the parents assured us that they had no problem with their children attending Christian devotions because they feel that the values that we bring to the Christian devotions or the values that are emphasised during those devotions are exactly the same as those that they have in Muslim religion. If we teach respect, they teach that as well". Another principal put it even more strongly when he claimed that "parents are very much supportive. They would say, eh, 'I schooled in 1956, I was taught religious education. I am what I am today because of what I was taught in those lessons. So, I want the same information to be passed on to my children".

For this reason, they resist the religion-in-education policy arguing that (a) it brings divisions into schools (b) it promotes morale degeneration- “......religious education was used to discipline learners and educators but nowadays children think that religious matters are for adults only thus their behaviour is worse than the behaviour of learners in the past", remarked one of the principals. On the other hand, principals with Hindu and Islamic orientations were not openly negative about the religion-in-education policy. To them, the greater equality between religions, at a policy level at least, would ensure that today's children would be spared their negative experiences. The Muslim principal stressed that "the new policy would allow us to create a different type of environment for learners who attend their schools, an environment where free association is the norm."

This study found that a number of schools had adopted some of the clauses from the South African Constitution (Act 108 of 1996a), South African Schools Act (Act 84 of 1996b) and the national religion policy into their school policies, not necessarily with the intention of applying them in their daily school lives, but to technically or administratively comply with the directives of departments of education. For instance, one of the school principals made it clear that at his school, the management team of the school (SMT) developed the policy and specified that there is freedom of religion within the school but in practice, "we would encourage learners strategically to attend ... assembly, where the prayer was said, hymns were sung and Scriptures were read. We were not telling them that we are Christians but the way things were done said it all." 
A similar strategy was followed at the other principal's school. She admitted that, when confronted by educators who felt that other religions must be accommodated in the school's religion policy, they would then open the clause that says, "Everyone has the right to believe in his own religion." The policy would be written like that, but when it comes to practice, "I see all learners going to the assembly, singing, praying, and reading the Bible". In another principal's words, "Religion policy changed on paper. Apart from the fact that people knew that it was voluntary, it was business as usual."

Indications from the data presented in this study are that, because they could not change their perceptions of and attitudes towards people of other religions, most of the principals who participated in the study have ignored the religion-in-education policy. Consequently, Christian religious education is still dominant in most South African schools since it is the religion of the majority. It is important however to mention that there were some exceptions in some cases. For instance, based on their own understanding and interpretation of the relevant Acts (the Constitution and SASA) and the national religion policy, they allocated a classroom for learners of other religions to observe their religions and allowed Muslim learners to go to the mosque on Fridays. They also worked harmoniously with SGB members from other religions, thereby demonstrating their accommodation to religious diversity. What they did not do is to change the religious ethos of their schools. Attendance of assemblies and other occasions where only Christian devotions were observed, were still compulsory. The section that follows discusses the study findings.

\subsection{Discussion}

Research on religious beliefs makes it clear that the preservation and development of the quality and distinctive nature of schools with a particular religious character depend on the faith, practice and commitment of the staff and the governing body. It is for this reason that the headship positions are usually reserved for members of such particular religion (Welsh Government 2011). It is not surprising therefore that the principals in this study found it their commitment to promote their religious teachings to the next generations. Their interpretation and understanding of legislation and educational policies manifested in areas such as policy development, learner admissions and educator appointment, teaching about religion, as well as religious observances.

\section{Policy development}

One of the functions of the governing body of the school as stated in Section 20 of the Schools Act, is to develop and adopt school policies, including those pertaining to religion. In describing the way in which policies are developed and implemented in their schools, in accordance with the Constitution and Section 22(1) of the Schools Act, the participating principals adopted some clauses to their school policies and the SGB acted as a rubber stamp' without any guarantee that such clauses would in fact be implemented (Marshall 2016; Koesel 2015; Guo and Zhang 2015). The implication is therefore that although the school policy preaches a message of religious accommodation, in practice unfair religious discrimination and indoctrination prevail (Ekanem and Ekefre 2013).

The case in point is Glenstantia Primary school who approved a new policy on religion in 2012 (citing the Constitution, the Religion-in-education policy and other documents as references) (Rousseau 2013). The SGB of this school decided that "Glenstantia Primary 
shall be a Christian based school". In so doing, this created an impression of bias rather than neutrality towards not only religion, but more importantly, a specific religion. Statements such as this are contraventions of Section 15 of the Constitution, as well as the Schools Act, both of which allow for religious expression, but only on an "equitable basis". As indicated earlier, such practice could only imply political accommodation of religion (Lamba 2016).

\section{Learner admission and educator appointment}

Principals in this study are aware of the religious changes that came about with the Constitution post-1994. Some of the changes they mentioned were that no learners may be refused admission to a school on religious grounds. Similarly, religion is not a ground for an educator to be denied appointment. On the basis of these changes, some principals in the study who grew up in the Hindu and Islamic faiths were appointed to Christian-oriented schools despite being non-Christians. Although the principals in this study allay parents' and appointees' fears by telling them that they should feel free to invite their religious leaders to come and address learners as part of their different religious observances, I doubt that the manner in which these conversations take place leave room for either debates or objections. I therefore concur with Gellel and Buchanan (2011), Mawhinney (2007), Lupul (1969) that such religious practices appear not a practical solution.

Literally, principals appear to be caring, accommodative and considerate by keeping records of religions represented in schools. It is important however to note that nowhere in school practices or processes is such information effectively utilised. Rousseau (2013) cited an incident where the two learners were sent home from Eben Dönges, a high school in the Western Cape, for wearing religious headgear. Sakeenah Dramat (16) was asked to remove her hijab, and her brother Bilaal Dramat (13) was asked to remove his fez, and they were told that they could not come back wearing their respective headgear. This was on the first day of the new term, and the learners were only able to return to school a week later, after the Western Cape Educational Department intervened.

\section{Teaching about religion}

The principals' narratives indicate that Religion Education is not given the attention it requires in their schools. One reason for this is ignorance of other religions. According to these principals, all they know is, for example, Christianity. It is, however, pertinent to note that there are principals in this study who admitted that in every religion there is something good (Sulaiman 2016; Fatima 2014; Welsh Government 2011). Even so, challenges remain. For instance, an educator of Muslim origin may not be able to teach about Christianity and vice versa. Thus, although these principals had a positive outlook on differences, they would not be able to help transform the teaching and learning of Religion Education in their schools. In this manner, it is difficult to gauge the genuineness of their claims. This could mean replication of the legislation and policies for political motivation.

The second group of principals - those who ignored the behaviour of educators towards the teaching of religion education-admitted that they were having difficulty imagining the teaching of religions different from theirs. Many expressed doubts about any 'good' 
coming out of other religions, hence their reluctance to have learners educated in these religions. Presumably, it is attitudes like these that have hardened the hearts of school principals in South Africa and elsewhere (Frankema 2012). The third and last group of principals - those who admitted that each religion is worth learning about-went further and played their leadership role. They either secured support material/resources and/or staff development opportunities. In so doing, these principals demonstrated the principles of religiously accommodating principals.

\section{Religious observance}

The principals' narratives revealed that morning devotions continued in the Christian way while other minority religions were marginalised in most schools. In some schools, learners and educators subscribing to other religions were not allowed to observe their religions, either in terms of dress code or in terms of worship. This concurs with studies that were conducted in countries such as Australia and Canada (Gellel and Buchanan 2011). In contrast, in some schools, classrooms were provided for the use of minority religious groups. Muslims were on occasion released to go to mosque on Fridays. In a way, the school principals interpreted their practices as conducting religious observances on an equitable basis as well as availing their facilities for such observances (DoE 2003; RSA 1996a, b).

Additionally, if an educator is not comfortable with the conducting of the morning assembly where Christianity is the dominating religion, the principal would excuse such educator by replacing him/her with a Christian member. Lastly, principals in this study are convinced that discussions they have with parents and interviewees are in a way a form of religious accommodation. It is for this reason that they claim to have parents' and learner support to conduct religious practices the way they do.

\section{Concluding remarks}

Learning from the fact that principals in this study are a product of the schools they were exposed to, for instance, one religion only, it appears a challenge for them to accommodate other religions without compromising their own. They would rather opt to unfairly discriminate against religious "Other" than to change their perceptions of and attitudes towards people of other religions. Because of this attitude, principals in this study appear to be politically accommodative to religious diversity. However, it became evident also that there are those that saw things differently in some instances. Based on the research evidence provided above, factors such as past experience and lack or inadequate leadership training played an influential role in their decision making abilities. I therefore recommend leadership training programmes that will liberate principals' minds from fear of the unknown and act beyond political peripheries.

Acknowledgements The authorship, and/or publication of this article work is supported by the University of Pretoria through the UP-Postdoctoral Research Fellowship Programme Grant. 
Open Access This article is distributed under the terms of the Creative Commons Attribution 4.0 International License (http://creativecommons.org/licenses/by/4.0/), which permits unrestricted use, distribution, and reproduction in any medium, provided you give appropriate credit to the original author(s) and the source, provide a link to the Creative Commons license, and indicate if changes were made.

Funding I received funding from the Department of Research and Innovation through Postdoctoral Research Fellowship Programme at the University of Pretoria for authorship, and/or publication of this article.

\section{Compliance with ethical standards}

Conflict of interest I declare that I have no financial interest or benefit arising from the direct application of this research, authorship, and/or publication of this article.

\section{References}

Abdool, A., Potgieter, F., Van der Walt, J. L., \& Wolhuter, C. (2007). Inter-religious dialogue in schools: a pedagogical and civil unavoidability. HTS, 63(2), 543-560.

Babbie, E. (2014). The basic of social research (6th ed.). USA: Wadworth.

Bilchitz, D. 2011. The Tension Between Freedom of Religion and Equality in Liberal Constitutionalism. The Problem of Freedom and Equality. The Journal of the Helen Suzman Foundation, 11-19.

Chidester, D. (2003). Religion education in South Africa: teaching and learning about religion, religions, and religious diversity. British Journal of Religious Education, 25(4), 261-278.

Chidester, D. (2002). Multiple voices: challenges posted for religion education in South Africa. In religious education in schools: ideas and experiences from around the world. Published by International Association for Religious Freedom (IARF). https://iarf.net/resources/publications/ReligiousEducation-in-Schools.pdf. Accessed 25 October 2017.

Chisholm, L. (2005). The politics of curriculum review and revision in South Africa in regional context. Compare: A Journal of Comparative and International Education, 35(1), 79-100.

Clandinin, D. J., Murphy, M. S., Huber, J., \& Orr, A. M. (2010). Negotiating narrative inquiries: living in a tension-filled midst. The Journal of Educational Research, 103, 81-90.

Craig, C. J. (2010). Research on the boundaries: narrative inquiry in the midst of organised school reform. The Journal of Educational Research, 103, 123-136.

Ekanem, B. S. A., \& Ekefre, E. N. (2013). Education and religious intolerance in Nigeria: the need for essencism as a philosophy. Journal of Educational and Social Research, 3(2), 303.

Fatima, N. (2014). Religious-conflicts-in-Nigeria-and-their-impacts-on-social-life. Global Journal of Arts, Humanities and Social Sciences, 2(4), 15-19.

Frankema, E. P. (2012). The origins of formal education in sub-Saharan Africa: was British rule more benign? European Review of Economic History, 16, 335-355.

Gellel, A., \& Buchanan, M. T. (2011). The impact of cultural religious values upon pre-service teachers' perceptions of their role as educators in Catholic religious schools. Journal of Beliefs and Values, 32(3), 317-328. https://doi.org/10.1080/13617672.2011.627688.

Grelle, B. (2005). Defining and promoting the study of religion in British and American schools. Religion and Education, 32(1), 23-41. https://doi.org/10.1080/15507394.2005.10012348.

Grey, D. E. (2014). Doing research in real world. London: Sage.

Greyling, J. (2017). Constitution says religion can be practiced 'at', not 'by' schools, court hears. NETWERK24. https://www.news24.com/SouthAfrica/News/constitution-says-religion-can-be-practiced-atnot-by-schools-court-hears-20170517. Accessed on 25 July 2017.

Gross, Z. (2010). Reflective teaching as a path to religious meaning-making and growth. Religious Education: The official journal of the Religious Education Association, 105(3), 265-282. https://doi.org/10. 1080/00344081003772014.

Guo, C., \& Zhang, F. (2015). Religion and social stability: china's religious policies in the Age of Reform. Third World Quarterly, 36(11), 2183-2195. https://doi.org/10.1080/01436597.2015.1067862.

Hornemann, M. (2013). China: tight state controls on religious education. FORUM 18 NEWS SERVICE, Oslo, Norway. http://www.forum18.org/. Accessed on 14 October 2017. 
Hussain, A., Salim, A., \& Naveed, A. (2011). Connecting the dots: education and religious discrimination in Pakistan: A study of public schools and Madrassas. United States Commission on International Religious Freedom. www.uscirf.gov. Accessed on 13 October 2017.

Jackson, L. (2015). Religion in Hong Kong education: representation in liberal studies textbooks. Asian Anthropology, 14(1), 43-56. https://doi.org/10.1080/1683478X.2015.1025595.

Johnson, B. \& Christensen, L. (2012). (4th Ed.). Educational Research. Quantitative, qualitative, and mixed approaches. Thousand Oaks, CA: Sage Publications. Inc.

Kaidaulovna, M. M. (2012). Consequences of religious illiteracy and overcoming it.

Kayaoglu, T. (2015). Explaining interfaith dialogue in the muslim world. Politics and Religion. https://doi. org/10.1017/s1755048315000267.

Koesel, K. J. (2015). The political economy of religious revival. Politics and Religion. https://doi.org/10. $1017 / \mathrm{s} 1755048315000231$.

Laliberte', A. (2016). Managing religious diversity in China: contradictions of imperial and foreign legacies. Studies in Religion/Sciences Religieuses, 45(4), 495-519. https://doi.org/10.1177/0008429816659351.

LaFollette, H. (1989). Freedom of religion and children. Public Affairs Quarterly, 3(1), 75-89.

Lamba, R. (2016). Gandhi's response to religious conflict. Studies in Religion/Sciences Religieuses, 45(4), 470-475. https://doi.org/10.1177/0008429816659097.

Li, J., \& Moore, D. (2014). Reconsideration of the coexistence of Buddhist temple education and state education in Xishuangbanna, China. British Journal of Religious Education, 36(2), 139-154. https:// doi.org/10.1080/01416200.2013.783791.

Lupul, M. R. (1969). Religion and education in Canada: a call for an end to hypocrisy. The Journal of Educational Thought (JET)/Revue de la Pensée Éducative, 3(3), 141-150.

McMillan, J., \& Schumacher, S. (2014). Research in education: evidence based inquiry (7th ed.). England: Pearson Education.

Marashe, J., Ndamba, G. T., \& Chireshe, E. (2009). The teaching of African traditional religion in primary schools in Zimbabwe: challenges and opportunities. Religious Education, 104(1), 38-50. https://doi. org/10.1080/00344080802615325.

Marshall, A. (2016). Religion as culture: understanding religious diversity and freedom in China and Canada. Studies in Religion/Sciences Religieuses, 45(4), 476-494. https://doi.org/10.1177/ 0008429816659096.

Marshall, A. (2009). Everyday religion and identity in a western Manitoban Chinese community: christianity, the KMT, foodways and related events. Journal of the American Academy of Religion, 77(3), 573-608.

Mawhinney, A. (2007). Freedom of religion in the Irish primary school system: a failure to protect human rights? Legal Studies, 27(3), 379-403. https://doi.org/10.1111/j.1748-121X.2007.00062.x.

Mertler, C. A. (2006). Action research. Teachers as researchers in the classroom. Thousand Oaks: SAGE Publications.

Mitchell, G. (1993). Religious Freedom in South Africa. In J. Kilian (Ed.), Religious freedom in South Africa (pp. 1-13). Pretoria: University of Pretoria Press.

Monette, D., Sullivan, T., \& De Jong, C. (2014). Applied social research: a tool for human services. USA: Cengage Learning.

Moore, J. R. (2009). Why religious education matters: the role of islam in multicultural education. Multicultural Perspectives, 11(3), 139-145. https://doi.org/10.1080/15210960903116563.

Mkhatshwa, S. 1998. Opening address on "Multi-religious education in South Africa". Problems and prospects in a pluralistic society. Published by the Research Institute for Theology and Religion, University of South Africa, Pretoria.

Nanbu, H. (2008). Religion in Chinese education: from denial to cooperation. British Journal of Religious Education, 30(3), 223-234. https://doi.org/10.1080/01416200802170151.

Nayyar, A. H., Salim, A. (2003). The Subtle subversion: The state of curricula and textbooks in Pakistan.

Patton, M. Q. (1990). Qualitative evaluation and research methods (2nd ed.). Thousand Oaks: Sage Publications. Inc.

Peters, F. (1998). Religion and Schools in Canada. Journal of Catholic Education, 1 (3). http:// digitalcommons.lmu.edu/ce/vol1/iss3/4. Accessed on 13 October 2017.

Quebec, 1975. Charter of human rights and freedoms. Web.

Roebben, B. (2010). Seeking sense in the city: European perspectives on religious education. Book Review, Australian eJournal of Theology, 17(1), 1-3.

Rosenblith, S., \& Bailey, B. (2008). Cultivating a religiously literate society: challenges and possibilities for America's public schools. Religious Education: The official journal of the Religious Education Association, 103(2), 145-161. https://doi.org/10.1080/00344080801909851. 
Rousseau, J. (2013). Hey, teacher, leave them kids alone! The Daily Maverick. http://synapses.co.za/heyteacher-leave-kids/. Accessed July 2015.

Roux, C. (2001). Religion in education in South Africa: myth or reality? Panorama. International Journal of Comparative Religious Education and Values, 13(1), 17-26.

Scott, S., \& McNeish, D. (2012). Leadership and faith schools: issues and challenges. Nottingham: National College for School Leadership.

Shortle, A. F. and Gaddie, R. K. (2015). Religious nationalism and perceptions of muslims and islam. Politics and religion. https://doi.org/10.1017/s1755048315000322.

Sooka, Y. L. (1993). A hindu experience of religious freedom in the South African context. In J. Kilian (Ed.), Religious freedom in South Africa (pp. 82-92). Pretoria: University of Pretoria Press.

Sulaiman, K. O. (2016). Religious violence in contemporary Nigeria: implications and options for peace and stability order. Journal for the Study of Religion, 29(1), 85-103.

Thamm, M. (2014). Religion in schools: Watershed case to ensure teaching and not preaching. The Daily Maverick. http://www.dailymaverick.co.za/article/2014-09-03-religion-inschools-watershed-case-toensure-teaching-and-not-preaching/\#.Vb88WU100dU. Accessed May 2015.

Xie, Y., Tong, Y., \& Yang, F. (2017). Does ideological education in China suppress trust in religion and foster trust in government? Religions, 8(94), 1-11. https://doi.org/10.3390/rel8050094.

\section{Legislation and Policies}

Department of Education. (2001). Manifesto on values, education and democracy. Pretoria: Government Printer.

Department of Education. (2003). National policy on religion and education. Government Printer: Pretoria.

European Convention on Human Rights (2010). Council of Europe. F-67075 Strasbourg cedex. www.echr. coe.int.

Malta, House of Representatives. (2009). Tfal eżentati mit-tagћlim tar-religjon: Parliamentary Question 11995. http://www.pq.gov.mt/PQweb.nsf/10491c99ee75af51c12568730034d5ee/ c1256e7b003e1c2dc1257669004e4bea? Open Document.

Republic of China (2004). The constitution of the republic of China. https://www.constituteproject.org.

Republic of South Africa. (1996a). The constitution of the republic of South Africa. Pretoria: Government Printer.

Republic of South Africa. (1996b). South African Schools Act (Act 84 of 1996). Pretoria: Government Printer.

Universal Declaration of Human Rights, (2015). Dignity and justice for all of us. General Assembly resolution, 217 A (III). United Nations Department of Public Information. December 10. United Nations.

Welsh Government. (2011). Ministry for education and skills. Faith in education. www.wales.gov.uk/ educationandskills. ISBN: 978075046359 1. Accessed 12 Sep 2017.

Maitumeleng Albertina Nthontho is a Lecturer in the Department of Education Management and Policy Studies, Faculty of Education, and University of Pretoria, South Africa. 